\title{
The Use of Prebiotics of Plant Origin in Functional Milk Products
}

\author{
Ozge Ozcan", Tulay Ozcan ${ }^{2, *}$, Lutfiye Yilmaz-Ersan², Arzu Akpinar-Bayizit ${ }^{2}$, Berrak Delikanli \\ ${ }^{1}$ Department of Medical Laboratory Techniques, Vocational College of Health Services, Kirklareli University, Turkey \\ ${ }^{2}$ Department of Food Engineering, Uludag University, Turkey
}

Copyright $\mathrm{C} 2016$ by authors, all rights reserved. Authors agree that this article remains permanently open access under the terms of the Creative Commons Attribution License 4.0 International License

\begin{abstract}
A food that contains biologically active compounds/components which beneficially affects one or more target functions such as reduction of chronic diseases in the body along with its nutritional effects is named as "functional product". Among these foods or beverages that are fortified through addition of exogenous functional compounds (i.e. prebiotics) or using microorganisms that produce biogenic compounds or have probiotic features (probiotics). Probiotics are described as cultures of live microorganisms that are beneficial to health when administered to humans or animals, improve properties of gastrointestinal microflora. Prebiotics cannot be digested by small intestinal enzymes but are fermented by probiotic bacteria the large intestine. Much research attention is focused on the combined use of probiotics and prebiotics, generally known as symbiotic, to get their synergistic health properties. This review provides an insight on the current knowledge about the potential sources of plant-based prebiotics used in dairy industry.
\end{abstract}

Keywords Prebiotic, Probiotic, Plants

\section{Introduction}

The food industry is currently focusing on which attribute is more important on consumers' preference. The global trend is the increasing demand for convenience and health-beneficiary foods, of which particularly boost the immune system, reduce the risk of disease, and enhance health. Such foods must fit into lifestyles of the society providing convenience of use, good sensorial attributes, and an acceptable price-value ratio [1]. The interest for such products constitutes current and future main research objectives in food innovations and has led to the development of foods defined as "functional foods".

Functional foods, can be described as "foods that contain some health-promoting component(s) beyond traditional nutrients" which demonstrate their effects in amounts that can normally be expected to be consumed in the diet, and are not pills or capsules, but part of the normal food pattern" [2-4]. In general, a food that nonetheless conveys consumers the essential nutrients but also extends its health benefits far beyond basic nutrition can be defined as functional food [5-7].

Milk is a complex mixture of components like biologically active substances i.e. immunoglobulin, enzymes, antimicrobial peptides, oligosaccharides, fatty acids, saccharides, hormones, cytokines and growth factors which designates it as "physiologically functional" food [8]. The dairy industry has responded to consumers' awareness and perception in functional foods by enhancing the existing health attributes of milk and milk products $[9,10]$.

Development of functional milk products, i.e. yogurt, cheese and fermented drinks, containing probiotics and prebiotics could be an alternative to enhance health promoting microbial flora in the intestine, which depend on age, diet, stress, disease and drugs taken [11-13].

\section{Probiotics}

The word "probiotic" was initially used as an antonym of the word "antibiotic." It is derived from Greek words proand biotos and translated as "for life" [14-17]. Food and Agriculture Organization (FAO) and World Health Organization (WHO) defined probiotics as "live microorganisms which when administered in adequate amounts confer a health benefit on the host" [18]. In other words, probiotics are the microorganisms (bacteria or yeasts) that can help to reestablish and recolonize the human intestinal microbiota to enhance beneficial health effects on the host [19].

Probiotic products with health claims should have viable microorganisms at levels of $10^{6}-10^{7} \mathrm{cfu} \mathrm{mL}^{-1}$ or $\mathrm{cfu} \mathrm{g}^{-1}$ or even at higher levels at the time of consumption [20-23]. Some selected strains used in dairy food products as probiotics are Lactobacillus, Bifidobacterium, Lactococcus, Streptococcus, and Saccharomyces (Table 1) [24-32]. 
Table 1. Cultures used as probiotic

\begin{tabular}{|c|c|}
\hline Lactic acid bacteria & $\begin{array}{l}\text { L. cellobiosus, L. delbrueckii, } \\
\text { L. brevis, L. acidophilus, L. reuteri, } \\
\text { L. curvatus, L. fermentum, } \\
\text { L. plantarum, L. jonhsonii, } \\
\text { L. rhamnosus, L. helveticus, } \\
\text { L. salivarius, L. gasseri }\end{array}$ \\
\hline Bifidobacterium species & $\begin{array}{l}\text { B. adolescentis, B. bifidum, } \\
\text { B. breve, B. infantis, } \\
\text { B. longum, B. thermophilum }\end{array}$ \\
\hline Bacillus species & $\begin{array}{l}\text { B. subtilis, B. pumilus, B.lentus, } \\
\text { B. licheniformis, B. coagulans }\end{array}$ \\
\hline Pediococcus species & $\begin{array}{l}\text { P. cerevisiae, } P \text {. acidilactici } \\
\text { P. pentosaceus }\end{array}$ \\
\hline Streptococcus species & $\begin{array}{l}\text { S. salivarius ssp. thermophilus, } \\
\text { S. intermedius }\end{array}$ \\
\hline Bacteriodes species & $\begin{array}{l}\text { B. capillus, B. suis, B. ruminicola, } \\
\text { B. amylophilus }\end{array}$ \\
\hline Propionibacterium species & P. shermanii, $P$. freudenreichii \\
\hline Leuconostoc species & L. mesenteroides ssp. mesenteroides \\
\hline
\end{tabular}

Probiotics which possess antimicrobial, antidiarrheal, and antiinflammatory propertiesy offer many clinical applications (Figure 1) [33].

The criterion to select and maintain the efficacy of a microorganism as probiotic are i) to have high technological properties which allow them to be manufactured and incorporated into food products keeping their viability and functionality with pleasant flavors, tastes or textures; ii) to be resistant to low $\mathrm{pH}$, gastric juice, bile juice, pancreatic juice, iii) to be able to survive through the upper gastrointestinal (GI) tract, and arrive alive and colonize at its site of action; iv) to be comparable to human gut microbiota; iv) to accumulate the microbial metabolites to prevent, manage and treat disorders and chronic diseases; and vi) to be able to function in the gut environment with adherence to intestinal cells surfaces and mucus glycoproteins via stimulation/suppression of beneficial bacteria and suppression of harmful bacteria [34-36].

Probiotic strains (especially Lactobacillus and Lactococcus species) inhibit the growth of pathogenic microorganisms [37], by occupying the mucosal layer and epithelial cell surface [38], and also by producing antimicrobial agents such as bacteriocins or bacteriocin-like molecules, organic acids, and hydrogen that could suppress the growth of harmful microorganisms [39].

The major limitation of probiotics is they must have high viability in the product and remain alive in the gut to exert their beneficial effects. To overcome this drawback the concepts of "prebiotics" or "colonic foods" have been developed.

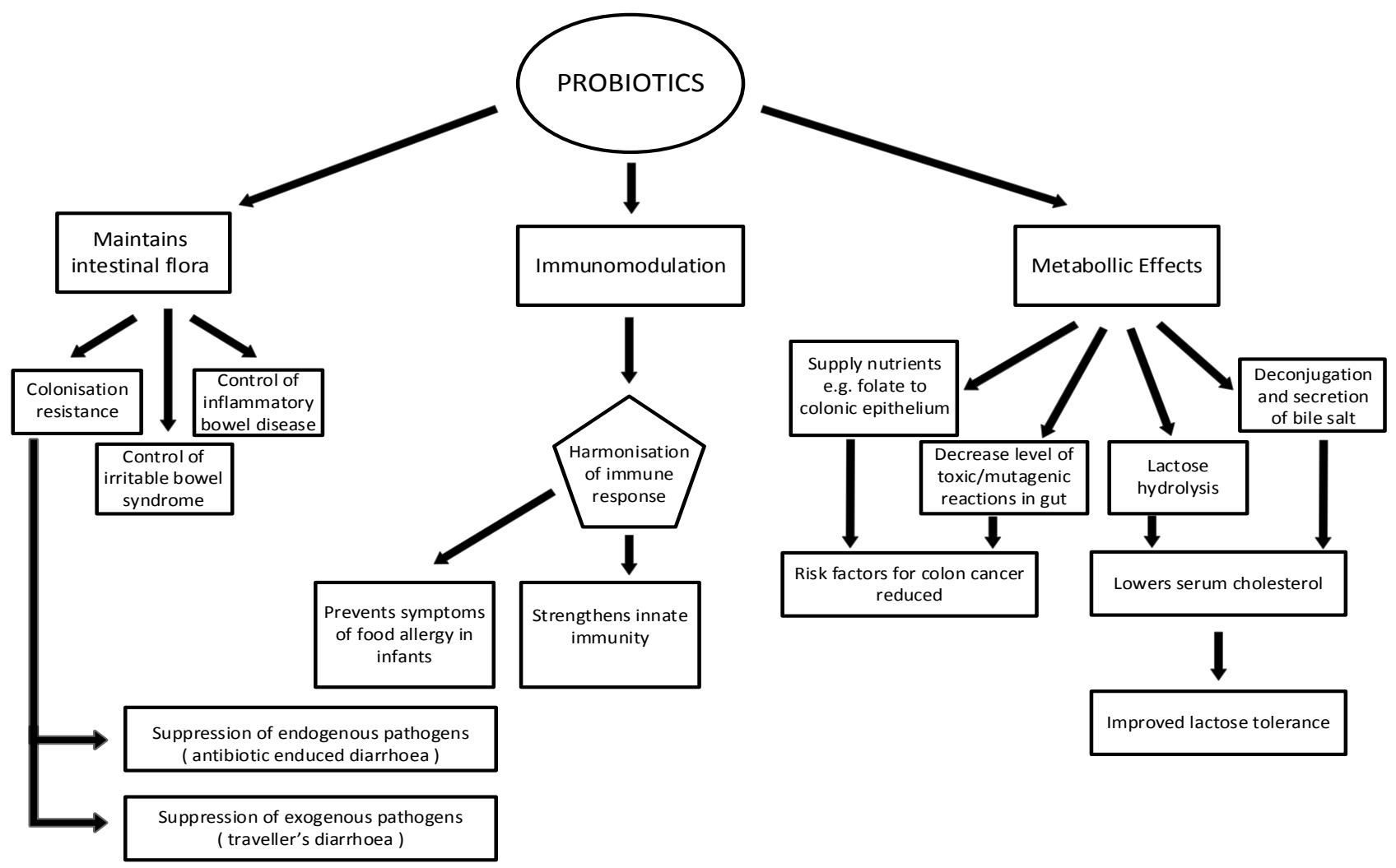

Figure 1. Potential and established effects of probiotic bacteria 


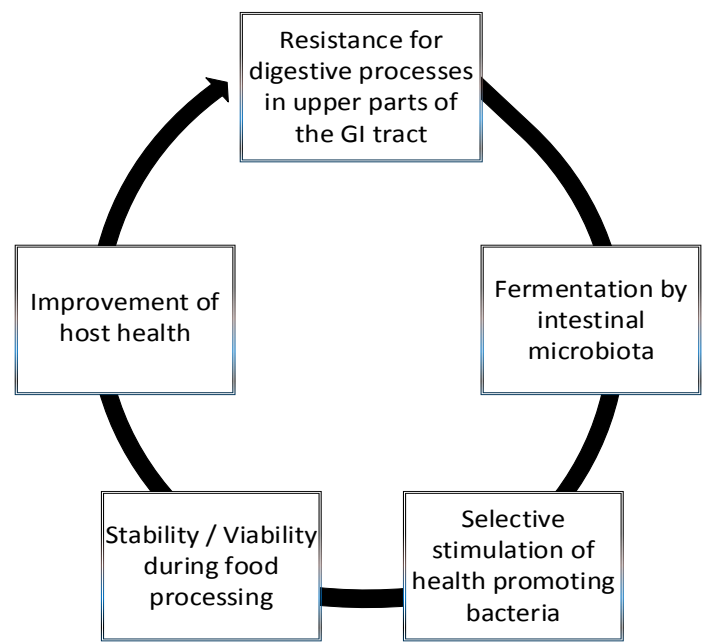

Figure 2. Criteria for a substance to be classified as a prebiotic

The concept of prebiotics was first introduced in 1995 [40], and they have gained attention in industry and academia due to their potential health benefits. Prebiotics are "non-digestible food ingredients that beneficially affect the host by selectively encouraging the growth and/or activity of one or a limited number of favorable bacteria in the colon" [41-44]. For a prebiotic the selection criteria is the substrate must not be hydrolyzed/absorbed in the stomach or small intestine, however, must be selectively used by microorganisms in the large intestine (Figure 2) [45-48].

The probiotics perform more efficiently in the presence of prebiotics, and the beneficial potential of live microorganisms could be enhanced by additional benefits of the prebiotic. The increased amount of prebiotics in the diet, the increased healthy bacterial gut flora of the host [49]. Prebiotics have the ability to improve the growth and metabolic activities of probiotics $[50,51]$.

\section{Prebiotics}

The function of a prebiotic component is selective stimulation of certain intestinal bacteria, particularly lactic acid producing microorganisms such as Bifidobacteria and Lactobacilli, resident in the gut rather than introducing an exogenous species. Prebiotics cannot be digested by enzymes in the small intestine but are fermented by probiotic bacteria in the large intestine. Short-chain fatty acids (SCFA), mainly acetate, propionate, and butyrate are formed via fermentation and due to the decrease of $\mathrm{pH}$ possible reduction in the numbers of pathogenic microorganisms can occur (Figure 3) [52-54]. The fermentation of prebiotics by the probiotic bacteria improves the host's health by enhancing the absorption of minerals such as $\mathrm{Ca}, \mathrm{Mg}$, and $\mathrm{Fe}$ and producing compounds capable of preventing colon cancer [40].

The prebiotic compounds can be classified based on their chemical nature, chain length or degree of polymerization (DP), mode of usage, etc. Depending on the chemical nature, prebiotic compounds are categorized into three types: saccharide derivatives (disaccharides, oligosaccharides and polysaccharides), proteins or peptides, and lipids [55].

Most of the prebiotics used as food adjuncts are saccharide derivatives and mainly from plants. This family of compounds includes several oligosaccharides (namely fructo-, gluco-, galacto-, isomalto-, xylo-, and soy-oligosaccharides), inulin, lactulose, lactosucrose, guar gum, resistant starch, pectin and chitosan. Potential plant sources for prebiotic carbohydrates are cereals and legume crops like barley, wheat, chickpea and lentils; vegetables like chicory, Jerusalem artichoke, onion, garlic, okra, and leek; and fruits like dragon fruit, jack fruit, palm fruit, nectarine and mushroom [56-64].

Foods may naturally contain prebiotics or can be fortified with prebiotics during manufacturing, in order to improve the functional efficacy of probiotics. When both prebiotics and probiotics are present in a food, then, those foods are referred to as "synbiotic" $[10,65]$.The "synbiotic" product, which refers to the "combination of prebiotics and probiotics", act as a nutritional supplement with the ultimate goal of conferring the advantageous health benefits to the host [66-69]. Synbiotics are particularly preferred since probiotics can tolerate oxygen, low $\mathrm{pH}$, and unfavorable temperature and survive in the digestive system when prebiotics are present [70-72].

Nowadays, prebiotics are included in many food formulations, especially in dairy products, in order to promote the growth of probiotics along with to improve the nutritional quality (Table 2). Therefore, incorporation of prebiotics into milk products, in particular those containing probiotic bacteria, would potentially lead to a product with improved mucosal surfaces of host and production of antimicrobial compounds to inhibit the pathogens, aside with fermentation and biopreservation of the food [73-75]. 


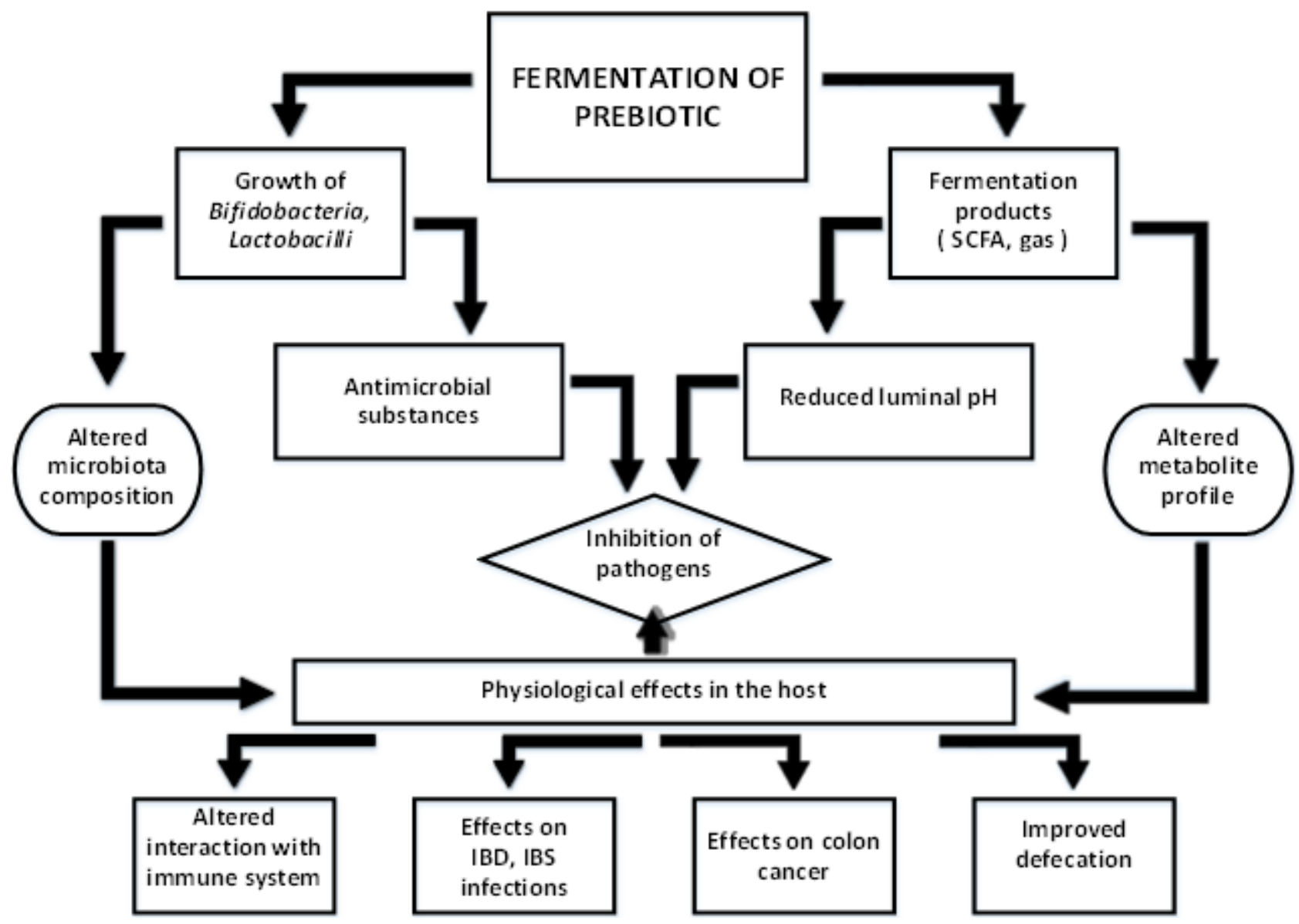

Figure 3. Potential and established effects of prebiotic (IBD: Inflammatory bowel disease, IBS: Irritable bowel syndrome)

Table 2. Some dairy product applications of prebiotic ingredients

\begin{tabular}{|c|c|c|c|}
\hline PREBIOTIC INGREDIENT & APPLICATION & FUNCTIONALITY & REFERENCE \\
\hline Lupin Seed & Fermented Milk & $\begin{array}{ll} & \text { Reduction of fermentation time } \\
\text { - } & \text { Increase probiotic bacteria count } \\
\end{array}$ & [76] \\
\hline Triticale bran & Yogurt & A new prebiotic and antioxidant source & [77] \\
\hline Lupin & Fermented Milk & - Increase growth and metabolic activity of Bifidobacteria & [78] \\
\hline $\begin{array}{c}\text { Oat bran, } \\
\text { Green Banana Flour }\end{array}$ & Dairy Fruit Beverage & - Increase the survival of Lactobacillus casei (LC-1) & [79] \\
\hline Lemon and Orange Fibers & Fermented Milk & $\begin{array}{l}\text { - } \\
\text { - } \\
\text { Enhance bacterial growth and survival of probiotic bacteria } \\
\text { Increase sensorial properties }\end{array}$ & [80] \\
\hline Lentil Flour & Yogurt & Improve the physical and rheological properties of yogurt & [81] \\
\hline $\begin{array}{c}\text { Pulse ingredients } \\
\text { (pea protein, chickpea flour, lentil } \\
\text { flour, pea fibre, soy protein } \\
\text { concentrate and soy flour) }\end{array}$ & Yogurt & $\begin{array}{l}\text { - Increase growth and metabolic activity of probiotic and } \\
\text { yogurt starter cultures }\end{array}$ & [82] \\
\hline Apple, Banana and Passion Fibers & Yogurt & $\begin{array}{l}\text { - } \quad \text { Improve the fatty acid profile of yogurts } \\
\text { - } \quad \text { Develop new high value-added fermented dairy products }\end{array}$ & [83] \\
\hline Tomato Pulp & $\begin{array}{l}\text { Dairy-Based Tomato } \\
\text { Spread }\end{array}$ & $\begin{array}{ll}\text { - } & \text { Enhance bacterial growth and survival of probiotic bacteria } \\
\text { - } & \text { Increase sensorial properties } \\
\text { Develop functional foods. }\end{array}$ & [84] \\
\hline Quinoa Flour & Fermented Milk & $\begin{array}{ll}\text { - } & \text { Increase nutritive value } \\
\text { - } & \text { Increase the appeal of the product to consumers }\end{array}$ & [85] \\
\hline Apple, Banana and Grape Flour & Fermented Milk & $\begin{array}{l}\text { - } \quad \text { Develop alternative for functional fermented milk } \\
\text { production } \\
\text { - } \quad \text { Increase the viability of probiotic strains }\end{array}$ & [86] \\
\hline $\begin{array}{l}\text { A Grain Mixture (wheat, rye, oat, } \\
\text { barley and millet) }\end{array}$ & Yogurt & $\begin{array}{l}\text { - } \quad \text { Reduction of energy in foods as sugar replacement } \\
\text { - } \\
\text { Increase the acceptance of fiber-enriched yogurt }\end{array}$ & [87] \\
\hline
\end{tabular}




\section{Conclusions}

Changes in lifestyle and eating habits have led to considerable multiplication of health problems and chronic diseases. Due to growing global concern on nutrition and personal health, functional foods are gaining public acceptance in many countries. Fermented foods are of great significance since they provide and preserve nutritious foods in a wide diversity of flavors, aromas and textures, while enriching the human diet. In this context, the consumer perception and demand for fermented dairy products with "health promoting" properties, such as synbiotic and probiotic products, have increased. This is a key factor driving value sales growth in global markets.

\section{REFERENCES}

[1] M. B. Roberfroid. Global view on functional foods: European perspectives, British Journal of Nutrition, Vol.88, No.2, 133-138, 2002.

[2] N. P. Shah. Functional foods from probiotics and prebiotics, Food Technology, Vol.55, No.11, 46-53, 2001.

[3] C. Desmond, R. P. Ross, E. O'Callaghan, G. Fitzgerald, C. Stanton. Improved survival of Lactobacillus paracasei NFBC 338 in spray-dried powders containing gum acacia, Journal of Applied Microbiology, Vol.93, No.6, 1003-1011, 2002.

[4] A. C. Ouwehand, S. Salminen, E. Isolauri. Probiotics: An overview of beneficial effects, Antonie Van Leeuwenhoek, Vol.82, No.1-4, 279-289, 2002.

[5] B. M. Vesler Boler, G. C. Fahey, Jr. Prebiotics of plant and microbial origin. In: Direct-fed Microbials and Prebiotics for Animals: Science and mechanisms of action, Callaway, T.R. and Ricke, S.C. (Ed.), pp. 13-26, 2012.

[6] P. V. Maria, C. de Sousa, E. F. dos Santos, V. C. Sgarbieri. The importance of prebiotics in functional foods and clinical, Food and Nutrition Sciences, Vol.2, No.2, 133-144, 2011

[7] A. Homayouni. Therapeutical effects of functional probiotic, prebiotic and symbiotic foods, Tabriz University of Medical Sciences, Tabriz, 2008.

[8] S. K. Bharti, N. K. Sharma, K. Murari, A. Kumar. Functional aspects of dairy foods in human health: An overview, Critical Review In Pharmaceutical Sciences, Vol.2, No.1, 35-42, 2012.

[9] M. Gobbetti, R. di Cagno, M. de Angelis. Functional microorganisms for functional food quality, Critical Reviews in Food Science and Nutrition, Vol.50, No.8, 716-727, 2010.

[10] H. Korbekandi, A. M. Mortazavian, S. Iravani. Technology and stability of probiotic in fermented milks. In: Probiotic and Prebiotic Foods: Technology, Stability and Benefits to the human health, Shah N. (Ed.), pp. 131-168, USA, 2013.

[11] Y. Vandenplas, G. Huys, G. Daube. Probiotics: An update, Jornal de Pediatria, Vol.91, No.1, 6-21, 2015.

[12] R. P. F. Guine, M. J. Lima. Overview and developments regarding functional foods and beverages, Current Nutrition and Food Science, Vol.4, No.4, 298-304, 2008.

[13] H. Hardy, J. Harris, E. Lyon, J. Beal, A. D. Foey. Probiotics, prebiotics and immunomodulation of gut mucosal defences: Homeostasis and immunopathology, Nutrients, Vol.5, No.6, 1869-1912, 2013.

[14] J. Schrezenmeir, M. de Vrese. Probiotics, prebiotics and synbiotics: Approaching a definition, American Journal of Clinical Nutrition, Vol.73, No.2, 361-364, 2001.

[15] J. M. T. Hamilton-Miller, G. R. Gibson, W. Bruck. Some insight into the derivation and early uses of the word 'probiotic', British Journal of Nutrition, Vol.90, No.5, 845, 2003.

[16] N. P. Shah. Probiotics and fermented milk. In: Manufacturing Yogurt and Fermented Milk, Chandan R. C. (Ed.), Blackwell Publishing Ltd., Oxford, U.K., pp.341-354, 2006.

[17] A. Kumar-Anal, H. Singh. Recent advances in microencapsulation of probiotics for industrial applications and targeted delivery, Trends in Food Science and Technology, Vol.18, No.5, 240-251, 2007.

[18] FAO/WHO. Guidelines for the Evaluation of Probiotics in Food. Report of a Joint FAO/WHO Working Group on Drafting Guidelines for the Evaluation of Probiotics in Food, London, Ont., Canada, 2002.

[19] A. Shafi, U. Farooq, K. Akram, Z. Hayat, M. Anjum-Murtaza. Prevention and control of diseases by use of pro- and prebiotics (synbiotics), Food Reviews International, Vol.30, No.4, 291-316, 2014.

[20] T. Mattila-Sandholm, P. Myllarinen, R. Crittenden, G. Mogensen, R, Fonden, M. Saarela. Technological challenges for future probiotic foods, International Dairy Journal, Vol.12, No.2-3, 173-182, 2002.

[21] G. Olaiz-Fernandez, J. Rivera-Dommarco, T. Shamah-Levy R. Rojas, S. Villalpando-Hernandez, M. Hernandez-Avila. National health and nutrition survey, National Institute of public health, Mexico, pp.131, 2006.

[22] T. Vasiljevic, N. P. Shah. Probiotics-from Metchnikoff to bioactives, International Dairy Journal, Vol.18, No.7, 714-728, 2008.

[23] C. H. Röble, M. Auty, N. Brunton, R. Gormley, F. Butler. Alginate coating as carrier of oligofructose and inulin and to maintain the quality of fresh-cut apples, Innovative Food Science Emerging Technology, Vol.11, No.1, 203-209, 2010.

[24] T. Klaenhammer. Probiotic bacteria: Today and tomorrow, Journal of Nutrition, Vol.130, No.2, 415-416, 2000.

[25] V. Krishnakumar, I. R. Gordon. Probiotics: challenges and opportunities, Dairy Industries International, Vol.66, No.2, 38-40, 2001.

[26] R. Puupponen-Pimia, A. M. Aura, K. M. Oksman-Caldentey, K. M. Mylla-rinen, P. Saarela, M. Mattila-Sanholm. Development of functional ingredients for gut health, Trends Food Science and Technology, Vol.13, No.1, 3-11, 2002.

[27] F. Holm. Gut health and diet: The benefits of probiotic and prebiotics on human health, The World of Ingredients, Vol.2, No.2, 52-55, 2003.

[28] M. J. Playne, L. E. Bennet, G. W. Smithers. Functional dairy 
foods and ingredients, The Australian Journal of Dairy Technology, Vol.58, No.3, 242-264, 2003.

[29] N. P. Shah. Probiotics and prebiotics, Agro-Food Industry Hi-Tech, Vol.15, No.1, 13-16, 2004.

[30] M. C. McKinley. The nutrition and health benefits of yoghurt, International Journal of Dairy Technology, Vol.58, No.1, $1-12,2005$.

[31] W. Krasaekoopt, B. Bhandari, H. Deeth. Survival of probiotics encapsulated in chitosan-coated alginate beads in yoghurt from UHT- and conventionally treated milk during storage, LWT-Food Science and Technology, Vol.39, No.2, 177-183, 2006.

[32] L. de Vuyst, G. Falony, F. Leroy. Probiotics in fermented sausages, Meat Science, Vol.80, No.1, 75-78, 2008.

[33] J. B. Ewaschuk, L. A. Dieleman. Probiotics and prebiotics in chronic inflammatory bowel diseases, World Journal of Gastroenterology, Vol.12, No.37, 5941-5950, 2006.

[34] A. G. Cruz, J. A. F. Faria, A. G. F. Van Dender. Packaging system and probiotic dairy foods, Food Research International, Vol.40, No.8, 951-956, 2007.

[35] K. Singh, B. Kallali, A. Kumar, V. Thaker. Probiotics: A review, Asian Pacific Journal of Tropical Biomedicine, Vol.179, No.1-3, 287-290, 2011.

[36] D. R. Mack, S. Ahrne, L. Hyde, S. Wei, M. A. Hollingsworth. Extracellular MUC3 mucin secretion follows adherence of Lactobacillus strains to intestinal epithelial cells in vitro, Gut, Vol.52, No.6, 827-833, 2003.

[37] G. S. Burr, D. M. Gatline, S. Ricke. Microbial ecology of gastrointestinal tract and the potential application of probiotics and prebiotics in finfish aquaculture, Journal of the World Aquaculture Society, Vol.36, No.4, 425-436, 2005.

[38] T. Shiba, Y. Aiba, H. Ishikawa, A. Ushiyama, A. Takagi, T. Mine, Y. Koga. The suppressive effect of Bifidobacteria on Bacteroides vulgatus, a putative pathogenic microbe in inflammatory bowel disease, Microbiology and Immunology, Vol.47, No.6, 371-378, 2003.

[39] S. C. Ng, A. L. Hart, M. A. Kamm, A. J. Stagg, S. C. Knight. Mechanisms of action of probiotics: Recent advances, Inflammatory Bowel Diseases, Vol.15, No.2, 300-310, 2009.

[40] G. R. Gibson, M. B. Roberfroid. Dietary modulation of the human microbiota: Introducing the concept of prebiotics, Journal of Nutrition, Vol.125, No.6, 1401-1412, 1995.

[41] M. B. Roberfroid. Prebiotics and probiotics: are they functional foods? American Journal of Clinical Nutrition, Vol.71, No.6, 1682-1687, 2000.

[42] G. R. Gibson, H. M. Probert, J. Van Loo, R. A. Rastall, M. B. Roberfroid. Dietary modulation of the human colonic microbiota: Updating the concept of prebiotics, Nutrition Research Reviews, Vol.17, No.2, 259-275, 2004.

[43] E. Isolauri. The role of probiotics in pediatrics, Current Pediatric Reviews, Vol.14, No.2, 104-109, 2004.

[44] M. B. Roberfroid. Prebiotics: The concept revisited, Journal of Nutrition, Vol.137, No.3, 830-837, 2007.

[45] A. Marini, F. Negretti, G. Boehm, M. Li Destri, D. Clerici-Bagozzi, F. Mosca, M. Agosti. Pro- and pre- biotics administration in preterm infants: colonization and influence on faecal flora, Acta Paediatrica, Vol.91, No.441, 80-81, 2003.

[46] G. Moro, S. Arslanoğlu, B. Stahl, J. Jelinek, U. Wahn, G. Boehm. A mixture of prebiotic oligosaccharides reduces the incidence of atopic dermatitis during first months of age, Archives of Disease in Childhood, Vol.91, No.10, 814-819, 2006.

[47] P. Scholtens, M. S. Alles, J. G. Bindels. Bifidogenic effects of solid weaning foods with added prebiotic oligosaccharides: Randomized controlled clinical trial, Journal of Pediatric Gastroenterology and Nutrition, Vol.42, No.5, 553-559, 2006.

[48] S. Seifert, B. Watzl. Inulin and oligofructose: Review of experimental data on immune modulation, Journal of Nutrition, Vol.137, No.11, 2563-2567, 2007.

[49] G. R. Gibson, R. A. Rastall, R. Fuller. The health benefits of probiotics and prebiotics. In: Gut Flora, Nutrition, Immunity and Health, Fuller R., Perdigon G. (Ed), Blackwell Publishing Ltd., Oxford, U.K., pp 52-76, 2003.

[50] B. S. Sekhon, S. Jairath. Prebiotics, probiotics and synbiotics: An overview, Indian Journal of Pharmaceutical Education and Research, Vol.1, No.2, 13-36, 2010.

[51] D. L. Topping, M. Fukushima, A. R. Bird. Resistant starch as a prebiotic and synbiotic: State of the art, Proceeding of the Nutrition Society, Vol.62, No.1, 171-176, 2003.

[52] S. I. Mussatto, I. M. Mancilha. Non-digestible oligosaccharides, Carbohydrate Polymers, Vol. 68, No.3, 587-597, 2007.

[53] G. T. Macfarlane, H. Steed, S. Macfarlane. Bacterial metabolism and health-related effects of galacto-oligosaccharides and other prebiotics, Journal of Applied Microbiology, Vol.104, No.2, 305-344, 2008.

[54] E. M. Quigley. Prebiotics and probiotics; modifying and mining the microbiota, Pharmacology Research, Vol.61, No.3, 213-218, 2010

[55] S. P. Ishwarya, P. Prabhasankar. Prebiotics: Application in bakery and pasta products, Critical Reviews in Food Science and Nutrition, Vol.54, No.4, 511-522, 2014.

[56] P. Fric. Probiotics and prebiotics renaissance of a therapeutic principle, Central European Journal of Medicine, Vol.2, No.3, 237-270, 2007.

[57] J. Stowell. Calorie control and weight management. In: Sweetners and sugar alternatives in food technology, Mitchell H. (Ed.), Blackwell Publishing Ltd. Oxford, U.K., 2007.

[58] O. Banuelos, L. Fernandez, J. M. Corral, M. Valdivieso-Ugarte, J. L. Adrio, J. Velasco. Metabolism of prebiotic products containing $\mathrm{b}(2-1)$ fructan mixtures by two Lactobacillus strains, Anaerobe, Vol.14, No.3, 184-189, 2008.

[59] A. Pompei, L. Cordisco, S. Raimondi, A. Amaretti, U. M. Pagnoni, D. Matteuzzi, M. Rossi. In vitro comparison of the prebiotic effects of two inulin-type fructans, Anaerobe, Vol.14, No.5, 280-286, 2008.

[60] E. Bruzzese, M. Volpicelli, V. Squeglia, D. Bruzzese, F. Salvini, M. Bisceglia, P. Lionetti, M. Cinquetti, G. Iacono, S. 
Amarri, A. Guarino. A formula containing galacto- and fructo- oligosaccharides prevents intestinal and extra-intestinal infections: An observational study, Clinical Nutrition, Vol.28, No.2, 156-161, 2009.

[61] G. Falony, T. Calmeyn, F., Leroy, L. de Vuyst. Coculture fermentations of Bifidobacterium species and Bacteroides thetaiotaomicron reveal a mechanistic insight into the prebiotic effect of inulin-type fructans, Applied and Environmental Microbiology, Vol.75, No.8, 312-319, 2009.

[62] D. C. Hernot, T. W. Boileau, L.L. Bauer, I. S. Middelbos, M. R. Murphy, K. S. Swanson, G. C. Fahey-Jr. In vitro fermentation profiles, gas production rates, and microbiota modulation as affected by certain fructans, galactooligosaccharides, and polydextrose, Journal of Agricultural and Food Chemistry, Vol.57, No.4, 1354-1361, 2009.

[63] G. Kelly. Inulin-type prebiotics: A review (Part 2), Alternative Medicine Review, Vol.14, No.1, 36-55, 2009.

[64] Y. Pan, Y. Sunayama, M. Nagata, M. Taniguchi, E. Takano, H. Inoue, H. Tamagake, H. Anzai. Cloning of a cDNA encoding the sucrose: Sucrose 1-fructosyltransferase (1-SST) from Yacon and its expression in transgenic rice, Biotechnology and Biotechnological Equipment, Vol.23, No.4, 1479-1484, 2009.

[65] K. J. Aryana, S. Plauche, R. M. Rao, P. McGrew, N. P. Shah. Fat-free plain yogurt manufactured with inulins of various chain lengths and Lactobacillus acidophilus, Journal of Food Science, Vol.72, No.3, 79-84, 2007.

[66] G. Puccio, C. Cajozzo, F. Meli, F. Rochat, D. Grathwohl, P. Steenhout. Clinical evaluation of a new starter formula for infants containing live Bifidobacterium longum BL999 and prebiotics, Nutrition, Vol.23, No.1, 1-8, 2007.

[67] J. P. Chouraqui, D. Grathwohl, J. M. Labaune, J. M. Hascoet, I. de Montgolger, M. Leclaire, M. Giarre, P. Steenhout. Assessment of the safety, tolerance and protective effect against diarrhea of infant formulas containing mixtures of probiotics or probiotics and prebiotics in a randomized controlled trial, American Journal of Clinical Nutrition, Vol.87, No.5, 1365-1373, 2008.

[68] M. A. Underwood, N. H. Salzmand, S. H. Bennett, M. Barman, D. A. Mills, A. Marcobal, D. J. Tancredi, C. L. Bevins, M. Sherman. A randomized placebo controlled comparison of 2 prebiotic/probiotic combinations in preterm infants: Impact on weight gain, intestinal micro biota and fecal short chain fatty acids, Journal of Pediatric Gastroenterology and Nutrition, Vol.48, No.2, 216-225, 2009.

[69] A. M. Vlieger, A. Robroch, S. Van-Buuren, J. Kiers, G. Rijkers, M. A. Benninga, R. T. Biesebeke. Tolerance and safety of Lactobacillus paracasei ssp paracasei in combination with Bifidobacterium animalis ssp lactis in a prebiotic containing infant formula: a randomised controlled trial, British Journal of Nutrition, Vol.102, No.6, 869-875, 2009.

[70] A. Spindler-Vesel, S. Bengmark, I. Vovk, O. Cerovic, L. Kompan. Synbiotics, prebiotics, glutamine, or peptide in early enteral nutrition: A randomized study in trauma patients, Journal of Parenteral and Enteral Nutrition, Vol.31, No.2, 119-126, 2007.

[71] C. Stanton, G. Gardiner, H. Meehan, K. Collins, G. Fitzgerald, P. B. Lynch, R. P. Ross. Market potential for probiotics, The
American Journal of Clinical Nutrition, Vol.73, No.2, 476-483, 2001

[72] J. Suskovic, B. Kos, J. Goreta, S. Matosic. Role of lactic acid bacteria and bifidobacteria in synbiotic effect, Journal of Food Technology and Biotechnology, Vol.39, No.3, 227-235, 2001.

[73] I. Siro, E. Kapolna, B. Kapolna, A. Lugasi. Functional food. Product development, marketing and consumer acceptance, Appetite, Vol.51, No.3, 456-467, 2008.

[74] R. Oliveira, A. Florence, P. Perego, M. Oliveira, A. Converti. Use of lactulose as prebiotic and its influence on the growth, acidification profile and viable counts of different probiotics in fermented skim milk, International Journal of Food Microbiology, Vol.145, No.1, 22-27, $2011 \mathrm{a}$.

[75] R. Oliveira, P. Perego, M. Oliveira, A. Converti. Effect of inulin as a prebiotic to improve growth and counts of a probiotic cocktail in fermented skim milk, LWT-Food Science and Technology, Vol.44, No.2, 520-523, 2011 b.

[76] C. Martinez-Villaluenga, J. Frias, R. Gomez, C. Vidal-Valverde. Influence of addition of raffinose family oligosaccharides on probiotic survival in fermented milk during refrigerated storage, International Dairy Journal, Vol.16, No.7, 768-774, 2006.

[77] R. Agil, F. Hosseinian. Dual functionality of triticale as a novel dietary source of prebiotics with antioxidant activity in fermented dairy products, Plant Foods for Human Nutrition, Vol.67, No.1, 88-93, 2012.

[78] C. Martinez-Villalueng, R. Gomez. Characterization of Bifidobacteria as starters in fermented milk containing raffinose family of oligosaccharides from lupin as prebiotic, International Dairy Journal, Vol.17, No.2, 116-122, 2007.

[79] K. B. Guergoletto, M. Magnani, J. San-Martin, J. C. G. T. Andrade, S. Garcia. Survival of Lactobacillus casei (LC-1) adhered to prebiotic vegetal fibers, Innovative Food Science and Emerging Technologies, Vol.11, No.2, 415-421, 2010.

[80] E. Sendra, P. Fayos, Y. Lario, J. Fernandez-Lopez, E. Sayas-Barbera, J. A. Perez-Alvarez. Incorporation of citrus fibers in fermented milk containing probiotic bacteria, Food Microbiology, Vol.25, No.5, 13-21, 2008.

[81] F. Zare, J. L. Boye, V. Orsat, C. Champagne, B. K. Simpson. Microbial, physical and sensory properties of yogurt supplemented with lentil flour, Food Research International, Vol.44, No.8, 2482-2488, 2011.

[82] F. Zare, C. Champagne, B. K. Simpson, V. Orsat, J. L. Boye. Effect of the addition of pulse ingredients to milk on acid production by probiotic and yogurt starter cultures, LWT-Food Science and Technology, Vol.45, No.2, 155-160, 2012.

[83] A. P. do Espirito-Santo, N. S. Cartolano, T. F. Silva, F. A. S. M. Soares, L. A. Gioielli, P. Perego, A. Converti, M. N. Oliveira. Fibers from fruit by-products enhance probiotic viability and fatty acid profile and increase CLA content in yogurts, International Journal of Food Microbiology, Vol.154, No.3, $135-144,2012$

[84] C. D. Staliano, R. C. R. Martinez, S. M. I. Saad. Beneficial microorganisms viability and sensory acceptance of a potentially synbiotic dairy-based tomato spread, LWT-Food Science and Technology, Vol. 62, No.1, 682-688, 2015. 
[85] S. N. Casarotti, B. M. Carneiro, A. L. B. Penna. Evaluation of the effect of supplementing fermented milk with quinoa flour on probiotic activity, Journal of Dairy Science, Vol.97, No.10, 6027-6035, 2014.

[86] S. N. Casarotti, A. L. B. Penna. Acidification profile, probiotic in vitro gastrointestinal tolerance and viability in fermented milk with fruit flours, International Dairy Journal, Vol.41, No.1, 1-6, 2015.

[87] K. Hoppert, S. Zahn, L. Janecke, R. Mai, S. Hoffmann, H. Rohm. Consumer acceptance of regular and reduced-sugar yogurt enriched with different types of dietary fiber, International Dairy Journal, Vol.28, No.1, 1-7, 2013. 